\title{
Increasing Students Learning Process and Outcomes through Matrix Strategy in Biodiversity Concept
}

\author{
St.Wahidah Arsyad, Sri Amintarti, Amalia Rezeki, Lisa Ignatia \\ Biology Education Department, Faculty of Teacher Training and Education \\ Universitas Lambung Mangkurat \\ Banjarmasin, Indonesia \\ amaliarezeki@unlam.ac.id
}

\begin{abstract}
The concept of biodiversity is taught in the second semester in the tenth grade of senior high schools. Based on the interview results to a Biology teacher in SMA Muhammadiyah 2 Banjarmasin, the concept of biodiversity has not reached the individual KKM which is $\geq 70$. In addition, complete lesson plans are not in accordance with the curriculum; therefore, some indicators of the curriculum have not been included into the lesson plans. This study aimed to improve the process and outcomes of students learning as well as to evaluate the responses of students and teachers. It was an action research conducted in two cycles. The subjects were students of class X A SMA Muhammadiyah 2 Banjarmasin in a number of 27 students. The performance during the process of the learning process increased in general from cycle I to cycle II. The performance assessment process supported by students activity gained excellent category, the performance assessment of students learning process gained categories, with the category of very good psychomotor, behavioral assessment by the category of very good character, social skills of students during learning with both category management and activities of the teacher during learning was on the very good category. The results of students learning during the learning process increased from cycle I to cycle II with completeness percentage of $94.84 \%$. The results during the learning process based on the value of LKS gained either category. At last, students and teacher responses showed a positive response.
\end{abstract}

Keywords-Biodiversity Concept, Matrix, Process and Learning Outcomes

\section{INTRODUCTION}

The biodiversity concept was carried out on the previous year by observation, assignment and discussion. However, there are still students who are passive so that the discussion is not effective as the material being discussed is not in accordance with the curriculum. Therefore, the curriculum discussion is recommended with the addition of recording and classifying the material into a table. Individual study results do not meet the specified individual school KKM that is $\geq 70$. Meanwhile, the RPP is incomplete because there are several indicators on the curriculum that have not been entered.
This study aims to improve students learning process and outcomes as well as evaluate the responses of students and teachers on the concept of biodiversity.

\section{METHOD}

This type of research is the Classroom Action Research (CAR) with 2 cycles based on [9]. The subjects of this study were the tenth grade students at SMA Muhammadiyah 2 Banjarmasin. This school is located at Jalan Mangga III RT. 22 No. 47 East Banjarmasin, South Kalimantan.

The qualitative data were obtained from the students' learning process and the responses of students and teachers through questionnaires as well as the data of students learning in the form of worksheets. Meanwhile, the quantitative data were obtained from the study in the form of pre-test and post test.

The survey analysis data were classified as qualitative data conducted in a descriptive way. Quantitative data analysis was carried out on a percentage basis. And the data analysis about students and teacher responses results was shown descriptively. Qualitative indicators are students learning in the form of assessment of students activity, performance assessment process of student learning, psychomotor assessment, behavioral assessment character, social skills assessment, and teacher assessment of activity of the first cycle to the second cycle of excellent category [5]. Quantitative indicators are students learning outcomes in the form of pre-test and post-test from the first cycle to the second cycle on complete category. Students achieve mastery set by the individual school. And the results during the learning process, namely from LKS results from cycle I to cycle II is on excellent category [5]. Then, students and teachers show positive response [1]. 


\section{RESULTS AND DISCUSSION}

A. Improved Students Learning Process Results from Cycle I to Cycle II

The Improved students learning process results from cycle I to cycle II in general was increased. It can be seen on Fig. 1-6.

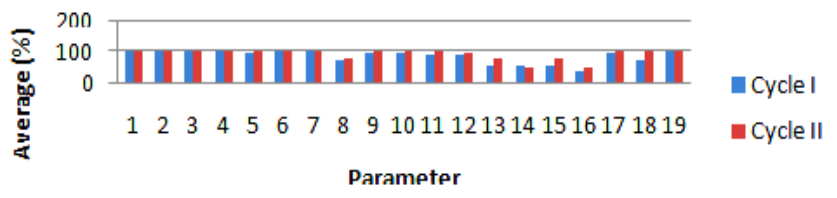

Fig. 1. The Average Results of Students Learning Process in Cycle I and Cycle II

The parameter information:

- Students listen and answer teacher's greeting.

- Students raise their hands when they are called.

- Students prepare to learn.

- Students pay attention to the teacher in apperception and respond to teacher's questions.

- Students work on the problems from the pre-test.

- Students receive information on the subject matter topic and their learning goals.

- Students pay attention to the delivery of information in general about the learning material.

- Students answer questions posed by the teacher.

- Students form study groups and joined the group members.

- Students help the teacher to distribute teaching materials and worksheets.

- Students pay attention to the explanation given by the teacher in the example and populate the matrix.

- Students discuss with members of the group in completing the worksheets.

- Students take turns to present the results in discussions.

- Students receive the teacher's award given for the best group.

- Students ask the teacher about the material that is not understood.

- Students make conclusions to learning materials on the day.

- Students work on the problems in the post-test.

- Students receive information about the subject at the next meeting.

- Students pay attention to the teacher closes the lessons and respond the greetings.
B. Performance Results of Students Learning Process in Cycle I and Cycle II

\begin{tabular}{rrr}
100 & 75,64 & 80,47 \\
\cline { 2 - 2 } & Cycle I & Cycle II
\end{tabular}

Fig. 2. The Average Performance Results of Students' Learning Process in Cycle I and Cycle II

\section{Psychomotor Results in Cycle I and Cycle II}

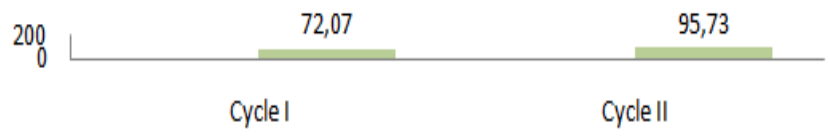

Fig. 3. The Average Psychomotor Results in Cycle I and Cycle II

\section{Character Behavior Observation Results in Cycle I and Cycle II}

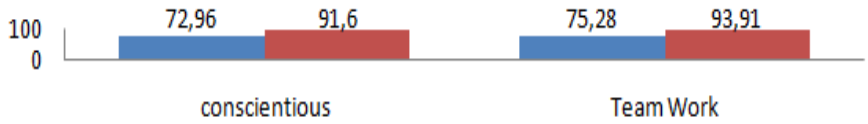

- Cycle I $₫$ Cycle II

Fig. 4. The Average Behavior Character in Cycle I and Cycle II

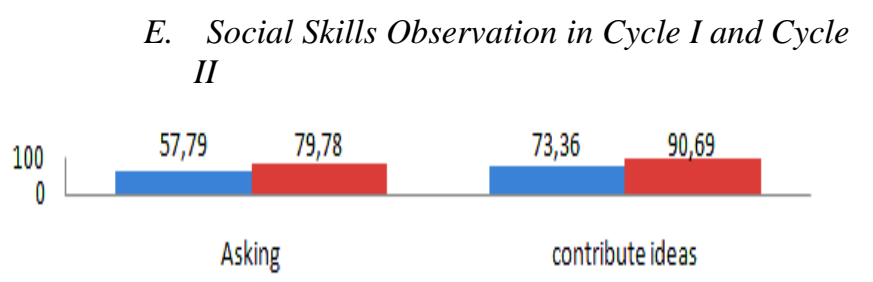

Cyclel mCyclell

Fig. 5. The Social Skill Average Rating in Cycle I and Cycle II

F. Results of Activities Master in Cycle 1 and Cycle II

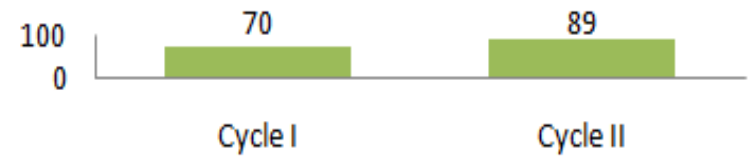

Fig. 6. Teacher Activity Average Score in Cycle I and Cycle II

The Increased students learning from cycle I to cycle 2 is affected by such things as follows:

1) The Activities of

Students in Learning in Cycle I to Cycle II

Students activities increased from Cycle I $(86.05 \%)$ to Cycle II (91.63\%), showing that the teacher's dominance is reduced. It is in line with [3] that the matrix strategy can devote attention to the lesson thinking, and critical thinking; 
improve the ability to organize, identify, and classify the material and activeness of students in learning.

2) Student

Learning

Process Performance in Cycle I to Cycle II

Students learning process performance increased from Cycle I $(75.64 \%)$ to Cycle II $(80.47 \%)$, showing a good implementation of the information provided by the teacher, then the information is managed by the students to fill out the matrix. It aims to increase the ability of students' understanding of information. This finding is consistent to an opinion by [11] that the matrix strategy enhances the ability to identify and classify the material. It makes it easy to understand the lesson and influence the outcome of the learning process.

3)

to Cycle II

Psychomotor in Cycle I

Psychomotor result increased from Cycle I (72.07\%) to Cycle II $(95.73 \%)$, showing the students' attention already led to a discussion of material so that students are actively following the discussion, give and respond to the opinions and appreciate suggestions. These results are consistent with [4] that increased students curiosity and answered the increasing cover topics.

4)

Cycle I to Cycle II

Character Behavior in

There was an increased character behavior in terms of meticulous Cycle I (72.96\%) and $(91.60 \%)$ Cycle II and cooperation $(75.28 \%)$ first cycle and $(93.91 \%)$ Cycle II. This finding is consistent with the opinion of Smith in [2] that the cooperative learning through small groups of students working together with friends maximizes the learning process so as to make them learn together well and carefully in the troubleshooting process.

5) to Cycle II

Social Skills in Cycle I

Increased social skills, in terms of asking Cycle I (57.79\%) and Cycle II (79.89\%) and contribute ideas/opinions (73.36\%) in Cycle I and $(90.69 \%)$ Cycle II. These results are consistent with [6] that it is done by asking to encourage the process and learning outcomes, gather information, check the student's understanding and evoked response. According to [8] by contributing students ideas/opinions Students work in learning.

6) The Activities of Teacher in Management Education in Cycle I to Cycle II

Teacher's activities increased from Cycle I (71.05\%) to Cycle II (89.47\%), showing that teacher optimizes the learning process. This is in accordance with the opinion of Uzer Usman [6] that a classroom management skill of teachers is to create and maintain an optimal learning condition.

\section{G. Improved Students learning outcomes on Biological Diversity concept with strategy matrix}

The improved students learning outcomes from the first cycle to the second cycle in general has also been completed. It can be seen in Fig. 7-8.

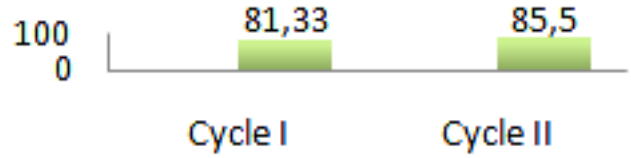

Fig. 7. The Average students worksheet results in cycle I and II

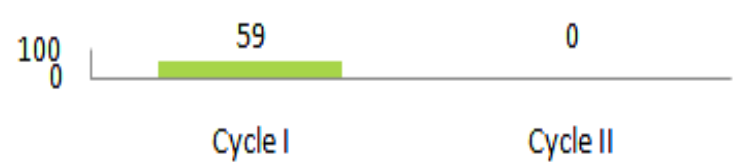

Fig. 8. The Average Test Results of the Pre and Post Test in cycle I and II

Students learning outcomes improvement from cycle 1 to cycle 2 is influenced by factors such as: 1)

Students worksheets in Cycle I to Cycle II

Students worksheets increased from Cycle I (81.30\%) and Cycle II $(85.49 \%)$, due to complete the task. The students worked together and helped each other in understanding the material. The matrix strategy is able to manage information through organizing concepts into a matrix.

2)

Cycle II

Post Test in Cycle I to

The rated post test in cycle I was $45.57 \%$ and cycle II was $88.79 \%$, the classical completeness of cycle I to cycle II was $94.84 \%$. The growing willingness of a person is associated with maturity, since maturity means readiness to implement prowess. Readiness to consider in the process of learning is also taken into account because students learn that there is readiness, then good study results are achieved [7].

\section{H. Responses of the Tenth Grade Students at SMA Muhammadiyah 2 Banjarmasin on Biological Diversity Concept with Matrix Strategy}

Learning through matrix strategy on Biological Diversity concept has received positive responses from students of class X A SMA Muhammadiyah 2 Banjarmasin, this can be seen in Fig. 9.

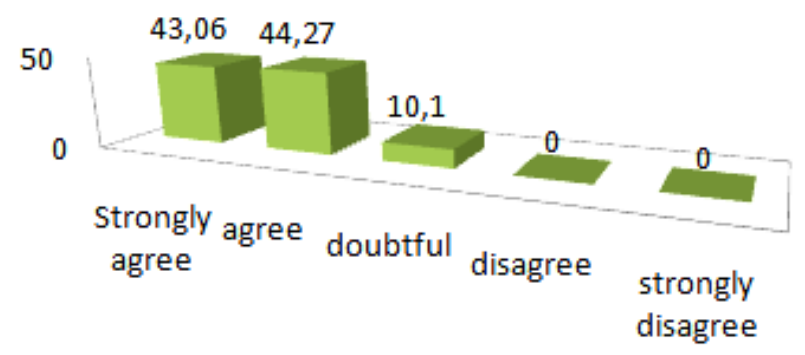

Fig. 9. Response Against Student Learning

Students questionnaire responses provide students answers which show agree inasmuch $87.33 \%$. Learning through matrix strategy received a positive response from the students of class X A SMA Muhammadiyah 2 Banjarmasin. 


\section{Teacher's responses during the Learning Activities on Biodiversity Concept through Matrix Strategy}

Learning through matrix strategy on biological diversity concept has received positive responses from the tenth grade biology teacher at SMA Muhammadiyah 2 Banjarmasin, this can be seen in Fig. 10.

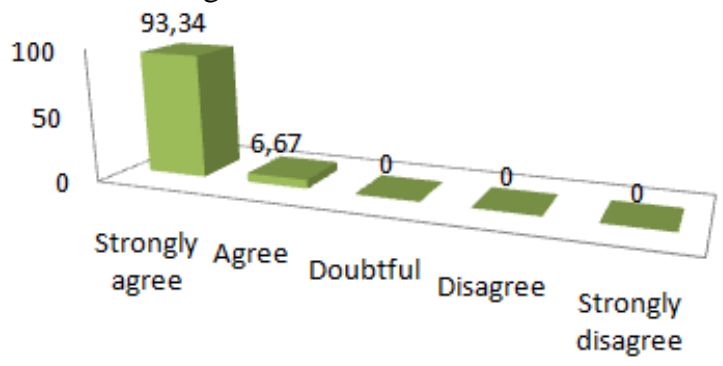

Fig. 10. Teacher's Response to Learning

Among 15 statements, 14 numbers obtained strongly agree answer and got the percentage inasmuch $93.34 \%$ and one answer was agree to the percentage of $6.67 \%$. Learning to use this matrix strategy received a positive response from the tenth grade biology teacher at SMA Muhammadiyah 2 Banjarmasin.

\section{CONCLUSION}

The increased learning process of students are because of: 1. Activities of students on Cycle I (86.05\%) to Cycle II $(91.63 \%) ; 2$. The performance of the students' learning process in cycle $1(75.64 \%)$ to Cycle II $(80.47 \%)$; 3. Psychomotor from Cycle I (72.07\%) to Cycle II (95.73\%); 4. Behavior character: meticulous Cycle I (72.96\%) and (91.60\%) Cycle II and co-operation (75.28\%) on Cycle I and (93.91\%) Cycle II; 5. Social skills: ask Cycle I (57.79\%) and Cycle II (79.89\%) and contribute ideas/opinions $(73.36 \%)$ on Cycle I (90.69\%) on Cycle II and 6. Teacher's activities from Cycle I (71.05\%) to Cycle II (89.47\%).

Then, the increased of students learning outcomes are due to 1. Students worksheets results from Cycle I $(81.30 \%)$ and Cycle II (85.49\%) and 2. Post-test rated on Cycle $1(45.57 \%)$ and Cycle II (88.79\%), increase in completeness classical in Cycle I to Cycle II was (94.84\%).

Matrix strategy on biological diversity concept received a positive response from students and teacher of biology at the tenth grade of SMA Muhammadiyah 2 Banjarmasin.

\section{ACKNOWLEDGMENT}

The authors thank Faculty of Teacher Training and Education, Universitas Lambung Mangkurat for the funding of BO-PTN 2016 of this research.

\section{REFERENCES}

[1] S. Arikunto, "Penelitian Tindakan Untuk Kepala Sekolah dan Pengawas," Yogyakarta: Adiyta Media, 2011.
[2] E. E. Barkley, K. P. Cross, and C. H. Major, "Collabotative Learning Techniques: Teknik-Teknik Pembelajaran," Bandung: Nusa Media, 2012.

[3] N. Faridah, "Efektifitas Strategi Matrix Ingatan Dalam Meningkatkan Pemahaman Siswa Pada Bidang Study Fiqih Di Mi Darul Faizin salafiyah Catak Gayam Jombang Tahun Pelajaran 2009/ 2010," Surabaya: Sunan Ampel. http://jiptiain--nurfaridah-8565-5-babii_pdf/. (Diakses pada tanggal: 14 Januari 2014), 2009.

[4] Kunandar, "Langkah Mudah Penelitian Tindakan Kelas Sebagai Pengembangan Profesi Guru," Jakarta: Rajawali Pers, 2011.

[5] N. M. Purwanto, "Prinsip-Prinsip dan Teknik Evaluasi Pengajaran," Bandung: PT Remaja Rosdakarya, 2012.

[6] Rusman, "Model-model Pembelajaran Mengembangkan Profesionalisme Guru," Jakarta: Rajawali Press, 2013.

[7] Slameto, "Belajar \& Faktor-Faktor yang Mempengarui," Jakarta: Rineka Cipta, 2010.

[8] R. E. Slavin, "Cooperative Learning Teori Riset dan Praktik," Bandung: Nusa Media, 2011.

[9] H. Susilo, C. Husnul and D. S. Yuyun, "Penelitian Tindakan Kelas Sebagai Sarana Pengembangan Kepropesionalan Guru dan Calon Guru," Malang: Bayu Media, 2012.

[10] Trianto. "Mendesain Model Pembelajaran Inovatif-Progresif Konsep, Landasan dan Implementasinya pada Kurikulum Tingkat Satuan Pendidikan (KTSP)," Jakarta: Kencana Perdana Media Group, 2013.

[11] H. Zaini, M. Bermawy, and A. A. Sekar, "Strategi Pembelajaran Aktif," Yogyakarta: CTSD, 2008. 